\title{
ARTIGOS
}

\section{IDEIA DE FUTURO EM POLÍTICA \\ E EDUCAÇÃO: UM DIÁLOGO COM ARENDT \\ MAURÍCIO LIBERAL AUGUSTO}

\section{RESUMO}

Faz-se o exame da força semântica contida nas noções de futuro em política e educação a partir do ensaio de Hannah Arendt "A crise na educação" (1958). Para a pensadora, a tradição legou uma concepção da política como fabricação (poiésis), retirando a dignidade própria da ação humana (práxis) nesse âmbito da vida ativa. o fenômeno político da natalidade - a irrupção de recém-chegados a mundo e a promessa de um novo início - serve como contraponto a desejo de fabricar seja a nova sociedade, seja o novo homem, no âmbito educacional. 0 uso abusivo do slogan de uma escola do futuro justifica um exame mais detido da atitude conservadora que Arendt confere à educação nos seus exercícios de pensamento político como forma de preservar a potencial novidade política dos recém-chegados ao mundo.

POLÍTICA • EDUCAÇÃO • FUTURO • ARENDT, HANNAH

\section{IDEA OF THE FUTURE IN POLITICS AND EDUCATION: A DIALOGUE WITH ARENDT}

\section{ABSTRACT}

This paper examines the semantic force contained in notions of the future in politics and education, based on Hannah Arendt's essay "Crisis in Education" (1958). For her, the tradition left a legacy regarding the conception of politics as a creation (poiésis), taking away the very dignity of human action (práxis) in this context of vita activa [active life]. The political phenomenon of birth, the eruption of newarrivals in the world and the promise of a new beginning, serve as counterpoints to the desire to create, be it a new society or be it a new man, in the educational context. The over-use of the slogan of a school of the future justifies a more detailed examination of the conservative attitude that Arendt bestows upon education in its exercise of political thought as a form of preserving the new political potential of new-arrivals in the world. 


\section{L'IDÉE D'AVENIR EN POLITIQUE ET EN ÉDUCATION: UN DIALOGUE AVEC ARENDT}

RÉSUMÉ

Il s'agit d'examiner la force sémantique contenue dans les notions d'avenir en politique et en éducation à partir de l'essai de Hannah Arendt "La crise dans l'éducation» (1958). Pour l'auteur, la tradition a légué la conception de politique en tant que fabrication (poièsis), en lui ôtant la dignité propre à l'action humaine (praxis) au sein de la vie active. Le phénomène politique de la natalité - l'irruption des nouveaux-venus au monde et la promesse d'un nouveau début - sert de contrepoint au désir de fabriquer soit une nouvelle société, soit le nouvel homme, dans le domaine de l'éducation. L'usage abusif du slogan d'une école de l'avenir justifie un examen plus attentif d'une attitude conservatrice qu'Arendt confère à l'éducation dans ses exercices de pensée politique comme forme de préserver la nouveauté potentielle des nouveaux-venus au monde.

POLITIQUE • ÉDUCATION • AVENIR • ARENDT, HANNAH

\section{IDEA DE FUTURO EN POLÍTICA Y EDUCACIÓN: UN DIÁLOGO CON ARENDT \\ RESUMEN}

Se efectúa un examen de la fuerza semántica presente en las nociones de futuro en politica y educación a partir del ensayo de Hannah Arendt, "La crisis en la educación” (1958). Para la pensadora, la tradición legó una concepción de la política como fabricación (poiesis), retirando la dignidad propia de la acción humana (praxis) en dicho ámbito de la vida activa. El fenómeno político de la natalidad - la irrupción de recién llegados al mundo y la promesa de un nuevo inicio - sirve como contrapunto al deseo de fabricar tanto la nueva sociedad como el nuevo hombre, en el ámbito educacional. El uso abusivo del eslogan de una escuela del futuro justifica un examen más detallado de la actitud conservadora que Arendt le otorga a la educación en sus ejercicios de pensamiento político como forma de preservar la potencial novedad política de los recién llegados al mundo. 
Nossa esperança está sempre pendente do novo que cada geração aporta; precisamente por basearmos nossa esperança apenas nisso, porém, é que tudo destruímos se tentarmos controlar os novos de tal modo que nós, os velhos, possamos ditar sua aparência futura. (ARENDT, 1992, p. 243)

OBJETIVO DESTE ARTIGO É O DE DISCUTIR A FORÇA SEMÂNTICA CONTIDA NAS NOÇÕES de futuro em política e educação a partir do ensaio "A crise na educação" (1958), de Hannah Arendt. Num primeiro momento, expõe-se o conceito de educação para a pensadora e as tensas relações entre educação e política no mundo moderno. O divórcio que Arendt sugere entre esses dois âmbitos é aqui explorado como uma tese original e de difícil equacionamento para seus intérpretes, e que aponta para o perigo de uma instrumentalização da educação, isto é, como se fosse própria a esse âmbito a tarefa de forjar um novo homem para uma nova sociedade, atribuição contestada por Arendt. Para tanto, sublinha-se tanto o conceito de ação (práxis) como o de fabricação (poiésis) - na acepção que Arendt lhes dá na obra A condição humana (2010a) - e a maneira como os compreende em termos estritamente políticos.

Num segundo momento, examina-se a fecundidade da concepção de educação em Arendt referida ao tema da natalidade. A atitude conservadora em termos educacionais - e não políticos, como ela bem adverte - visa a salvaguardar a possibilidade da novidade contida no fenômeno da natalidade, isto é, no fato de que o mundo é constantemente invadido pela chegada de novos seres humanos, "estrangeiros" que, portanto, necessitam ser apresentados ao mundo, familiarizarem-se com ele, a fim de que possam fazer dele a sua morada e a das gerações 
seguintes. A ambiguidade que a natalidade comporta em termos educacionais - apresentar e proteger o mundo, a um só tempo - é aqui tomada como limite à seguinte questão: como preparar as novas gerações para um mundo novo sem usurpar desses recém-chegados "sua própria oportunidade face ao novo"?

O exemplo máximo da tentativa de fabricar um homem novo se deu com as experiências totalitárias no mundo moderno, tema explorado por Arendt em Origens do totalitarismo (1989). A ousadia e a radicalidade dessa obra se revelam justamente na tentativa de recuperar a dignidade da política, rebaixada como nunca com aquele evento histórico. Em sua obra posterior, A condição humana (2010a), Arendt faz um longo exame do caráter instrumental da política, reduzida a meios para a consecução de fins a ela estranhos: a política reduzida à satisfação das necessidades vitais. Essas questões funcionam como uma pequena digressão para, no momento seguinte, pensar um problema equivalente no âmbito da educação, isto é, levantar que a sua dignidade - ou o seu sentido - podem estar ameaçados quando a educação deixa de ser vista, prioritariamente, como tendo sentido em si mesma e passa a ser percebida através da lógica meramente utilitária, como o ingresso em uma universidade, por exemplo, ou como meio de difusão de supostas competências necessárias a um mercado de trabalho.

Por fim, com o processo de esvaziamento da política contemporânea, o artigo se encerra em considerações sobre a perda de densidade das ideias de passado, presente e futuro e suas implicações para o âmbito da educação, uma vez que, por personificar de alguma forma o passado, o professor, como porta-voz legítimo de uma herança que se funda em tradições públicas e compartilhadas, vê o seu trabalho ameaçado por um "futuro presentificado" que ameaça o passado com o esquecimento. A ideia de viver como prisioneiro de um futuro presentificado - diga-se de passagem que escola do futuro é um slogan recorrente no discurso educacional - é que justifica um exame mais detido do lugar que Arendt confere à educação nos seus exercícios de pensamento político.

\section{A EDUCAÇÃO COMO INSTRUMENTO DA POLÍTICA}

A máxima toda pedagogia é política e toda política é pedagógica, vinculada ao pensamento do educador Paulo Freire, revela como política e educação contraem relações que, no limite, anulam as possíveis e desejáveis distinções entre ambas. No entanto, se não é possível negligenciar essas relações - quanto mais num tempo em que a educação se tornou um desafio político de primeira ordem -, é oportuno recuperar a distinção entre educação e política e o modo pelo qual se possam relacionar sem que uma seja tragada pela outra. Essa relação, bem como outras questões relativas ao âmbito educacional ocupam as reflexões de Hannah Arendt 
no ensaio "A crise na educação", publicado na Partisan Review (1958) e, depois, como parte da coletânea Between Past and Future: Six Exercises in Political Thought (1961). O ensaio figura como uma espécie de filho único no conjunto de textos arendtianos, pois, ainda que a educação apareça de forma dispersa em outros textos, só ali o tema da educação é alçado ao foco da análise de Arendt.

Anos antes, porém, por ocasião da réplica à resenha que Eric Voegelin fez de Origens do totalitarismo, Hannah Arendt (2008, p. 423) já sublinhava:

\section{[...] minha principal crítica ao atual estado das ciências políticas e históricas se refere à sua crescente incapacidade de fazer dis- tinções. [...] O resultado é uma generalização em que as próprias palavras perdem qualquer significado [...] em que tudo o que há de distinto desaparece.}

Conforme aponta Duarte (2013), o esforço analítico de Arendt para estabelecer distinções não implica uma cisão estanque, mas pressupõe relacionar o que se distinguiu. Nesse sentido, por mais problemático que seja estabelecer o limite entre educação e política, seria equívoco instaurar um corte radical entre os dois âmbitos, pois significaria negar que todo limite a um só tempo une e separa. Assim, embora Arendt acentue, como se verá adiante, a distinção entre educação e política, também sugere a impossibilidade de pensar a ação educativa sem referência ao âmbito político: "essas distinções, embora de forma nenhuma arbitrárias, dificilmente correspondem a compartimentos estanques no mundo real, do qual, entretanto, são extraídas" (ARENDT, 2009, p. 63).

A seguir, tomar-se-á o depoimento de uma professora de História como um ponto de partida frisante (e de forma alguma isolado) da dança das fronteiras entre o âmbito da educação e o da política. Dele se fará uma extrapolação para caracterizar melhor o tema da implicação mútua entre política e educação, os problemas daí decorrentes, bem como algumas hipóteses de trabalho. Veja-se o depoimento:

\footnotetext{
Como quase todos os historiadores, escolhi a profissão porque pretendia mudar o mundo através do ensino de História. "Conhecer o passado para entender o presente e mudar o futuro" foi o lema de muitas gerações de historiadores, inclusive da minha, que viveu a abertura política no final da década de 1970. Acompanhamos intensamente a volta dos exilados, o surgimento dos movimentos sociais de bairros e favelas, a fundação do PT, a eleição do Brizola e o projeto de educação popular de Darcy Ribeiro. Abriam-se muitos campos de atuação para mudar o mundo. Eu escolhi o caminho da educação popular. (ABREU, 2009, p. 98, grifos nossos)
} 
Se o mundo mudou face aos esforços de educadores que se identificam com o depoimento acima, é difícil saber. De qualquer forma, pretende-se colocar sob suspeita a ideia - hoje cercada de empatia - de que seja tarefa de um educador "mudar o mundo através do ensino". À empatia e à suspeita, temos uma explicação. A empatia liga-se a um quase truísmo, pois qual educador não pretendeu, em algum instante de sua vida profissional, "mudar o mundo através do ensino"? Já a suspeita advém de reflexões suscitadas pelo ensaio "A crise na educação", de Hannah Arendt.

A compreensão que se teve do ensaio, iluminada pelo conjunto da obra de Arendt, sugere que a educação não pode pretender dizer como deve ser o mundo futuro, nem ditar o que deve ser feito para transformá-lo, mas conhecer e compreender como o mundo é. Ressalte-se que a autora não pretende banir a ideia de que o mundo possa ser transformado: nada estaria mais distante de suas reflexões políticas, pois, para Arendt (1992, p. 242), o conservadorismo em política,

\footnotetext{
[...] aceitando o mundo como ele é, procurando somente preservar o status quo [...], não pode senão levar à destruição, visto que o mundo, tanto no todo como em parte, é irrevogavelmente fadado à ruína do tempo, a menos que existam seres humanos determinados a intervir, alterar, a criar aquilo que é novo.
}

Daí ela afirmar que o novo sempre assume a feição de um milagre - um evento que rompe com as expectativas de continuidade e reprodução -, pois sempre se pode contar com o inesperado e o improvável das ações humanas, "porque cada homem é único, de sorte que, a cada nascimento, vem ao mundo algo singularmente novo” (ARENDT, 2010a, p. 222-223). Ocorre que, para Arendt, a renovação de um mundo comum por meio da ação é tarefa a ser cumprida no âmbito da política, e não no da relação pedagógica entre professores e alunos numa instituição escolar. Se, para Abreu, "abriam-se muitos campos de atuação para mudar o mundo", o âmbito adequado para levar a cabo tal transformação, ao menos na perspectiva de Arendt, é o da política, da ação entre iguais no espaço público.

Apesar da evidente dimensão política que a educação assume no mundo moderno, Arendt sugere, na contramão das pedagogias ali surgidas (CUSTÓDIO, 2011), uma nítida distinção entre educação e política, num esforço original de distinguir para relacionar e compreender esses dois âmbitos das relações humanas.

\section{FUNDANDO UMA NOVA ORDEM}

A ideia de fundar um mundo novo a partir da educação é uma utopia tão antiga quanto aquela encontrada nas páginas de A República, de Platão. 
Um exemplo moderno dessa utopia se encontra em Emílio, de Rousseau. E, para Arendt (1992, p. 225), essa utopia não apenas encontrou expressão conceitual e política nos escritos do genebrino, como dela se derivou a ideia generalizada e amplamente compartilhada de que "a educação tornou-se um instrumento da política, e a própria atividade política foi concebida como uma forma de educação".

Para Arendt, a desconfiança de Platão e Rousseau com a política dadas a imprevisibilidade, a irreversibilidade e a fragilidade das ações ${ }^{1}$ levou-os a pôr a educação a serviço de um ideal político, supostamente realizável por meio da educação de um homem novo, pois "parece natural iniciar um novo mundo com aqueles que são por nascimento e por natureza novos" (ARENDT, 1992, p. 225). Assim formulado o problema, a pergunta acerca do sentido da educação é obscurecida, pois, antes que o pensamento se ocupe dela, a resposta já surge: resguardadas as diferenças entre os dois pensadores, a tarefa de educar se transforma na de forjar um homem novo para uma nova sociedade.

A esse respeito, Boto (1996, p. 176) sublinha que, para os revolucionários franceses que tomaram para si a tarefa de forjar a educação, “se tratava de uma história em que o futuro já era quase passado, na medida em que, descartados o acaso e a indeterminação inscritos no tempo, acreditava-se numa rota já profetizada - quase uma fatalidade - cuja imanência deveria ser apenas revelada”. Ora, como toda utopia, o que quer que nela se realize deve habitar o futuro. Assim, é sintomático que Arendt (2001, p. 33), em Sobre a revolução, sugira que o próprio conceito de revolução como algo inteiramente novo não existia antes das duas grandes revoluções do fim do século XVIII, a francesa e a americana:

\section{Que as revoluções estavam prestes a entrar numa era inteiramente nova tinha já sido anteriormente afirmado pela instituição do ca- lendário revolucionário, onde o ano de execução do rei e da procla- mação da república foi contado como o ano primeiro.} reflete sobre os limites de um trabalho educativo. A esse respeito, ver os textos "Educação após Auschwitz" e "Educação e emancipação", ambos em Educação e Emancipação (2000), em que Adorno coloca sob forte suspeição a ideia de que a educação poderia emancipar 0 homem no sentido kantiano de emancipação.
Enfim, as ideias de futuro, de novo e de mudança há muito se associam à esfera da educação, e a força dessa trindade enraíza-se na crença transformadora da educação para a construção de um futuro político promissor. ${ }^{2}$ No caso da educação brasileira, desde o Manifesto dos Pioneiros da Educação Nova, de 1932, o discurso dominante exorta os profissionais a educar sob a égide do novo (VIDAL, 2013). Tudo se passa como se os educadores já habitassem a nova escola, que deve dar guarida ao novo professor, que está de posse de uma nova pedagogia, que tem como alvo um novo aluno, e assim por diante.

Em Falas do novo, figuras da tradição, Cordeiro (2002) revela como o discurso pedagógico dos anos 1970 e 1980 foi profundamente marcado pela ideia do novo, da mudança, e como naqueles anos se combateu 
fortemente um suposto ensino tradicional - suposto porque carente de uma descrição sistemática -, ao qual se atribuíram as mazelas da educação no país. O estudo evidencia como o vocabulário de combate então utilizado pelos renovadores fora derivado de âmbitos distintos da educação, não raro tendo origem na esfera política (quando não na político-partidária), e sendo frequentemente marcado por palavras de ordem e slogans presentes originalmente não no escorregadio campo das chamadas ciências da educação, mas nos movimentos sociais e nas lutas políticas que então se travavam em prol da redemocratização do país.

Se não se pode nem se deve negligenciar a potencial dimensão política da educação como introdução dos recém-chegados no mundo, isso não equivale a fazer da educação, parafraseando a máxima de Clausewitz, uma continuação da política por outros meios. Assim, ao escolher a escola como palco da mudança político-social, os educadores que partilham dessa visão talvez não percebam que fazem da sala de aula um simulacro da vida política, comumente travestido sob o signo de “escola democrática”. Em posição totalmente contrária a esse preceito, Arendt (1992, p. 226) considera que pertence

\footnotetext{
[...] à própria natureza da condição humana o fato de que cada geração se transforme em um mundo antigo, de tal modo que preparar uma nova geração para um mundo novo só pode significar o desejo de arrancar das mãos dos recém-chegados sua própria oportunidade face ao novo.
}

Diante disso, o que significa para ela "preparar uma nova geração para um mundo novo”, já que se atribui à instituição escolar exatamente esse sentido formativo? Ou, para ir ao ponto mais sensível do problema, como é possível ao educador não usurpar “dos recém-chegados sua própria oportunidade face ao novo” (ARENDT, 1992, p. 226).

\section{ACOLHER OS NOVOS E DIZER: ISTO É O MUNDO}

Como pode perceber qualquer pessoa que convive com crianças, para elas, a novidade do mundo brota como mágica diariamente, pois, recém-chegadas que são, tudo lhes parece admiravelmente novo. Mas isso só é verdadeiro, sublinha Arendt (1992, p. 226), para aqueles que são novos no mundo, não para o mundo: "O mundo no qual são introduzidas as crianças [...] é um mundo velho, isto é, um mundo pré-existente, construído pelos vivos e pelos mortos”. Ela recorda que toda nota de dólar traz impressa o lema Novus Ordo Seclorum (uma nova ordem no mundo) e que o significado de Novo Mundo - num país constituído por imigrantes como os Estados Unidos - retira sua força da expressão Velho Mundo: 
O papel político que a educação efetivamente representa em uma terra de imigrantes, o fato de que as escolas não apenas servem para americanizar as crianças mas afetam também a seus pais, e de que aqui as pessoas são de fato ajudadas a se desfazerem de um mundo antigo e a entrar em um novo mundo, tudo isso encoraja a ilusão de que um mundo novo está sendo construído mediante a educação das crianças. (ARENDT, 1992, p. 226)

Ingressar nesse novo mundo no qual aportam os imigrantes (pais e filhos) significa tomar parte de um éthos social e simbólico da cultura americana que glorifica o novo. A igualdade de oportunidades é um dos princípios professados como parte desse éthos e que o acesso público à escolarização materializa. Para Arendt, a crise da educação norte-americana não se deve a um suposto atraso em relação aos padrões europeus de ensino, tampouco ao fato de os Estados Unidos serem um país jovem. A crise na educação tem estreita relação com a crise política que acometeu o mundo moderno a partir das experiências totalitárias numa sociedade de massas e que resvalou para âmbitos que Arendt considera pré-políticos (BENVENUTI, 2010), como a família e a educação.

De acordo com Arendt, as pretensas soluções encontradas pelos educadores americanos para promover uma educação de massas com vistas a igualar oportunidades acabaram mesclando o pathos do novo e modernas teorias educacionais europeias sob a divisa da progressive education deweyana. Arendt (1992, p. 228) conclui que a crise da educação americana "apresenta um problema imensamente difícil por ter surgido sob as condições de uma sociedade de massas e em resposta às suas exigências". Em outras palavras, a crise que acometeu a educação não tem um significado restrito à sociedade americana. Se é a crise dos desafios de uma educação de massas, pode acometer todo e qualquer país que tenha escolhido como desafio político universalizar a educação.

Arendt (1992, p. 242) formulou uma concepção original do processo educativo, cujo traço é a natureza conservadora que atribui à educação:

[...] parece-me que o conservadorismo, no sentido de conservação, faz parte da essência da atividade educacional, cuja tarefa é sempre abrigar e proteger alguma coisa - a criança contra o mundo, o mundo contra a criança, o novo contra o velho, o velho contra o novo. Mesmo a responsabilidade ampla pelo mundo que é aí assumida implica, é claro, uma atitude conservadora. Mas isso permanece válido apenas no âmbito da educação, ou melhor, nas relações entre adultos e crianças, e não no âmbito da política, onde agimos em meio a adultos e com iguais. 
Assim, um educador que pretenda “mudar o mundo através do ensino" pode incorrer no equívoco de, em vez de preservar a novidade em potencial que habita cada novo recém-chegado - no caso, seus alunos -, inventar ele próprio essa novidade, usurpando dos alunos a possibilidade de empreendê-la por si mesmos, se assim o desejarem:

\begin{abstract}
[...] exatamente em benefício daquilo que é novo e revolucionário em cada criança é que a educação precisa ser conservadora; ela deve preservar essa novidade e introduzi-la como algo novo em um mundo velho, que, por mais revolucionário que possa ser em suas ações, é sempre, do ponto de vista da geração seguinte, obsoleto e rente à destruição. (ARENDT, 1992, p. 243, grifo nosso)
\end{abstract}

Portanto Arendt insiste em preservar um limite entre política e educação, inclusive por acreditar que a própria possibilidade da renovação de um mundo comum implica uma atitude conservadora em educação. Por trás dessa atitude (que é política por excelência), está o cuidado com o mundo e o zelo em relação à promessa da novidade que advém em cada nascimento. Ao mundo, que é a morada dos recém-chegados e será o palco de sua ação política, a atitude conservadora confere durabilidade e proteção. À promessa contida no nascimento, ela conserva a potencialidade da futura ação espontânea e criativa. Da mesma forma, o limite entre educação e política está intimamente relacionado ao fato de que o ingresso na vida política representa um novo nascimento do sujeito, agora livre da autoridade, seja da família, seja da instituição escolar. A esse respeito, Bárcena (2006, p. 225, grifo nosso) sublinha que o educador não deve

\section{[...] aspirar a crear un mundo nuevo con seres nuevos. Ésta es una tentación totalitaria. Mas bien, representa un mundo más antiguo, en cierto modo inmemorial, un mundo que es tiempo y que se transmite creativamente para que la pregunta por el sentido no quede cancelada. ${ }^{3}$}

Se o educador não deve aspirar à criação de um mundo novo a partir daqueles que são novos no mundo, isso vai ao encontro da compreensão de Arendt de que o agir, a ação política, também não significa fabricar uma nova sociedade. Assim, a educação não deve ser compreendida como fabricação de um homem novo, tampouco de um novo mundo. Sua visão, justamente por contrariar o que de ordinário se postula como tarefa da educação e da política, não se evidencia de imediato.

Há, entretanto, uma dimensão fundamental no argumento de Arendt que não se pode negligenciar. Sem o dizer explicitamente, ela põe em relevo um aspecto que tanto em política quanto em educação se

\section{3}

argumentativa, Duarte (2007, p. 85) observa que Arendt "é crítica em relação a projetos educacionais que politizam a educação, considerando-os autoritários e mesmo contraditórios, já que toda tentativa de produzir o novo impede na realidade a sua aparição". 
vê cada vez mais recusado: trata-se de acolher a ideia de que a existência de projetos políticos e educacionais comporta também uma indeterminação. Arendt (1992, p. 92, tradução modificada) é taxativa quando diz que imprevisibilidade não significa falta de previsão: "Unicamente o total condicionamento, vale dizer, a total abolição da ação, pode almejar algum dia fazer face à imprevisibilidade”.

No entanto, tudo se passa como se, no âmbito da política e da educação, bastasse um bom plano feito por especialistas, assim como a existência de gestores competentes que se põem a executá-lo a fim de se criarem as condições para um mundo planejado de antemão. Sem negar a importância do saber de um especialista, tampouco o sentido inerente ao ato de planejar, a desmedida ênfase com que os problemas políticos e educacionais são resumidos a uma solução técnica só aponta para um crescente declínio e esvanecimento seja da política, seja da educação. Os dois âmbitos se veem constantemente tentados a buscar soluções que reduzem ao mínimo a espontaneidade da ação, procurando abrigar-se na segurança dos meios com vistas aos fins pretendidos, isto é, à imagem da fabricação.

Ao modo de uma digressão, convém retomar a moldura conceitual de A condição humana, especialmente a interpretação de Arendt sobre a filosofia política de Platão. Tal digressão repousará sobre o conceito de obra/fabricação (work) para que se possa, adiante, remetê-la ao âmbito da educação.

\section{USURPANDO A DIGNIDADE DA AÇÃO POLÍTICA}

Para Arendt, a emergência do totalitarismo significou uma dupla falência: a do pensamento político ocidental e a da própria atividade política, na medida em que esta perdera sua dignidade no rol das atividades humanas. Arendt insiste, entretanto, que a tradição não é todo o passado. Assim, como toda tradição é seletiva, ela resgata experiências políticas que não mereceram registro por parte da tradição. Como sublinha Drucker (2000, p. 205), “aquelas possibilidades positivas que ficaram apenas insinuadas na história [e que] podem ser redescobertas e apropriadas", pois poderia "ocorrer que somente agora o passado se abrisse a nós com inesperada novidade e nos dissesse coisas que ninguém teve ainda ouvidos para ouvir" (ARENDT, 1992, p. 130).

Como uma reflexão nascida da crise que acometeu o mundo moderno (PORCEL, 2013), a análise histórico-política de Arendt parte dos acontecimentos e a eles permanece vinculada, pois lançam luz sobre a compreensão do passado. Mas ela assinala que uma crise põe a descoberto problemas que só se revelam com sua emergência, podendo libertar preconceitos que não oferecem mais resposta a questões ou até mesmo acirrá-los. Seja como for, o aspecto importante de uma crise na educação 
é a oportunidade por ela oferecida à reflexão. Assim, ela não é, por princípio, danosa: "só se torna um desastre quando respondemos a ela com juízos pré-formados” (ARENDT, 1992, p. 223). Ora, a crise que acomete a educação e a indistinção cada vez mais acentuada entre os âmbitos da política e da educação é um convite a refletir, seja sobre o sentido da educação, seja sobre o significado do passado, isto é, da história.

Arendt olha o passado visando a identificar experiências políticas singulares, ignoradas pela tradição, mas capazes de iluminar o presente, tal como a experiência da Atenas pré-platônica. Ela nutre uma forte suspeita de que a compreensão platônica da política fora realizada olvidando a experiência real pela qual os atenienses viviam a política do dia a dia. Nesse sentido, o empreendimento de Arendt (1992, p. 44) se assemelha a uma tentativa de fazer um inventário histórico sobre o esquecimento da política:

\section{A filosofia política implica necessariamente a atitude do filósofo para com a política; sua tradição iniciou-se com o abandono da política por parte do filósofo, [no caso, Platão] e o subsequente retorno deste para impor seus padrões aos assuntos humanos.}

O "abandono da política por parte do filósofo" está estreitamente ligado, para Arendt, ao julgamento e à morte de Sócrates, experiência que ela resgata a partir da análise que faz de Apologia, Teeteto e Menon, de Platão. ${ }^{4}$ Nesse resgate, surge um Sócrates que se defende publicamente diante de seus acusadores e concidadãos, reafirmando sua importância e seu interesse para a vida política da cidade. A condenação de Sócrates pelos atenienses faria com que Platão, seu discípulo, passasse a desconfiar da persuasão, qualidade retórica fundamental para a vida da polis, onde, por atos e palavras, os cidadãos livres agiam no interesse comum em razão de um mundo comum. Desconfiar da capacidade humana de ação política não seria o mesmo que retirar toda a dignidade da ação quando ela emerge entre os homens? E não foi em nome dessa mesma dignidade da qual atos e palavras se revestem que Platão, indignado, viu ser condenado à morte aquele a quem tanto admirava? ${ }^{5}$

A análise que Arendt empreende da parábola da caverna, no livro VII de A República, de Platão, revela como a desconfiança inicial acabou se convertendo em pura hostilidade da filosofia para com a política. Daí em diante, um fosso se abria entre os homens de ação e os homens de pensamento. A filosofia cedera à tentação de "impor seus padrões aos assuntos humanos”, derivando do campo das ideias a forma pela qual as ações políticas deveriam ocorrer.

Na interpretação da parábola, surge o personagem Sócrates, sua vida dedicada à polis, seu julgamento e sua morte. A experiência política vivida por Sócrates em Atenas não autoriza, pensa Arendt, que se

4 No ensaio "Arendt y Sócrates", Villa (2008, p. 119-120, tradução nossa) sublinha três aspectos do Sócrates arendtiano. $\bigcirc$ primeiro, resgatado em Apologia, refere-se ao Sócrates que pretendia evitar que "os cidadãos de Atenas vivessem adormecidos pelo resto de seus dias e atuassem sem uma autêntica reflexão moral". O segundo, resgatado em Teeteto, "é - Sócrates 'parteiro', que desfaz os preconceitos e evidências de seus interlocutores ajudando-os a conhecer seus próprios pensamentos". Por fim, o terceiro Sócrates, resgatado em Menon, "é o Sócrates 'torpedo', espécie de peixe [arraia] elétrico que paralisa e emudece a todos aqueles que o tocam". Cabe ressaltar que Villa não compartilha da forma como Arendt se apropria do Sócrates platônico. Numa carta a Jaspers, de 10 de julho de 1956, Arendt (2010b, p. 138) revela que, "Desde el proceso de Sócrates, es decir, desde que la polis procesó al filósofo, hay un conflicto entre política y filosofía que yo intento rastrear". 
cristalize na tradição a separação entre ação e pensamento, conforme estabelece o legado platônico. Ao contrário, em Sócrates, ação e pensamento são atividades que caminham juntas, donde a máxima socrática "Só sei que nada sei" ser um forte testemunho de que o filósofo nunca pretendeu ensinar nada a ninguém, tampouco impor a outrem sua opinião (doxa), mas, ao contrário, conhecendo outras opiniões (doxai), procurava alargar o quanto possível a compreensão do mundo, quer para si, quer para seus interlocutores em vista do bem da cidade. ${ }^{6}$

Ao recusar a oferta do exílio ou o pagamento de uma multa para se livrar da condenação à morte, Sócrates legou, na interpretação de Arendt, não apenas um exemplo de conduta ética, mas a compreensão de que o sentido da política se volta para o cuidado de si e com a polis, isto é, de que a política é um fim em si mesma. Assim, se escolhermos viver tendo Sócrates por companhia, tornamo-nos capazes de escolher aquilo que não devemos fazer, mas não o que fazer (conosco e com os outros). E isso certamente está por trás do grande interesse de Arendt pela figura de Sócrates quanto ao tema do totalitarismo. Ela nutria profunda admiração por aqueles que foram capazes de dizer "Não, isso eu não posso fazer”, diferentemente de Eichmann, por exemplo, incapaz de pensar o significado da deportação de milhões de pessoas para as fábricas de extermínio.

Surpreendentemente, a filosofia política de Platão, toda ela construída na forma de diálogos, nutre um não disfarçado temor de que o diálogo entre os cidadãos constitua a forma pela qual os homens se relacionam politicamente - isto é, que juntos, animados por princípios, opinem e decidam o que é de interesse comum para a cidade. Por isso, pretende simplesmente abolir o diálogo por meio do governo do rei-filósofo, aquele que sabe:

As ideias tornaram-se padrões de medida somente depois que o filósofo deixou o céu límpido das ideias e retornou à escura caverna da existência humana. [...] ele [o filósofo] nos fala da perda de orientação [...] da cegueira que atinge seus olhos, da angustiosa situação de não ser capaz de comunicar o que viu e do verdadeiro perigo para sua vida que daí surge. É nesse transe que o filósofo apela para o que ele viu, as ideias, como padrões e normas e, finalmente, temendo por sua vida, as utiliza como instrumentos de dominação. (ARENDT, 1992, p. 149)

Não é gratuito o fato de que os primeiros diálogos de Platão - os mais próximos, portanto, da morte de Sócrates - acabem sem solução (aporia), quando não num mútuo convite para que os interlocutores voltem outro dia a debater o assunto em questão. mentestituirá a ação (práxis) - em que liberdade, pluralidade e esponta-
neidade habitam - pela fabricação (poiésis). Conhecendo a ideia (eidos)
do bem, poderá o rei-filósofo moldar a cidade conforme o padrão e a 
norma que pode contemplar, ainda que essa operação se dê ao custo de abolir a liberdade das ações e a pluralidade característica de todo espaço genuinamente público. Como toda liberdade implicada na ação comporta uma ilimitada imprevisibilidade, é contra essa insegurança ante os efeitos da ação que o filósofo pretenderá edificar sua cidade. A ação (práxis) passa a ser concebida como fabricação (poiésis), com vistas a abolir a imprevisibilidade do resultado das ações políticas. ${ }^{7}$

A política concebida a partir da fabricação (poiésis) sugere uma correspondência com as artes e com os ofícios, o que pressupõe um saber especializado - no caso, o do estadista. Analogamente, como todo objeto fabricado, a política deixa de ter um sentido e passa a ser um instrumento, um meio para a consecução de algum fim outro que não ela própria.

Da mesma forma, se a violência é um dado inerente à fabricação porque não se pode fabricar um objeto sem violentar de alguma forma a natureza -, derivou-se a noção de que a violência é inerente à política, o que Arendt contesta ao longo de sua obra. Para ela, esse legado platônico sobre a política seguiu praticamente inalterado até Marx, que retoma essa tradição, mas também assinala seu fim, quando pretende realizar a própria filosofia na política, ou seja, fazer história.

O que justifica essa digressão é justamente a suspeita de que as relações entre educação e política ainda estejam profundamente marcadas por uma compreensão da política como fabricação. A hipótese que aqui se levanta é a de que esse modo de compreensão da política como meio para a consecução de fins a ela extrínsecos foi transposto para o âmbito da educação. Assim, o ensino deixa de ser animado por um princípio que busca pelo sentido e passa a servir a uma finalidade, passando a ser concebido como apenas um meio para a realização de fins estranhos a ele, entre os quais aqui importa destacar a tentativa de fabricar o futuro.

Com isso não se pretende afirmar que a educação em geral e o ensino institucionalizado não se relacionem, em alguma medida, com o porvir; tampouco que seja possível educar sem o estabelecimento de um currículo, de metas e objetivos a se alcançar. Conforme destaca Cruz (1999, p. 46): “Las generaciones que nos seguirán son la única superficie sobre la que podemos escribir el futuro. El hombre nuevo, si tal expectativa todavía conserva alguna virtualidad, no se construye ni se produce: se deja que sea”. Ora, parece não haver dúvida de que essa expectativa não só se conserva, como é indissociável do âmbito da educação. Entretanto, isso não significa que se vá escrever o futuro fabricando o homem novo.

A esse respeito, Lefort observa que todo ideal de educação - o sentido com o qual ela está investida - guarda íntima relação com o ideal de homem que determinada sociedade forja para si mesma. Espantado com a recusa de certo ideal humanista de educação na França em fins

A esse respeito, Duarte (2000, p. 194-195) sublinha: "Para que as idéias pudessem ser aplicadas ao mundo da política, era preciso que a própria atividade política fosse concebida segundo os moldes da fabricação, atividade na qual a distinção entre 'saber e executar' constitui um desdobramento natural, pois só se podem organizar os meios e passar à execução de algo uma vez que se tenha percebido anteriormente a imagem ou forma (eidos) do produto que se vai fabricar". 
dos anos 1970, o autor retomava a experiência da Florença renascentista ${ }^{8}$ no que se refere ao cultivo de uma cultura geral. Para ele, esse princípio, que significa uma ruptura com a escola latina medieval, implica que

\section{[...] a educação não possui mais limites definidos [...]. Em certo sentido, ela acolhe a indeterminação, já que quem aprende está sendo requisitado, não tanto para dominar um certo lote de co- nhecimentos, mas sim para travar um novo relacionamento com o saber. (LEFORT, 1999, p. 211)}

Antes de pretender restaurar um modelo humanista de educação, o gesto de Lefort tem em comum com a análise de Arendt (1992, p. 223) o fato de que uma crise na educação "nos obriga a voltar às questões mesmas e exige respostas novas ou velhas, mas de qualquer modo julgamentos diretos”. Ora, a dimensão política da educação se revela tanto em relação ao passado, quanto em relação ao presente e ao futuro, ainda que de formas distintas, como se verá adiante. Nunca é demais recordar que o ensaio "A crise na educação" está inserido na obra Entre o passado e o futuro (1992), cujo subtítulo diz: seis exercícios de pensamento político. Portanto, as distinções e relações entre educação e política que Arendt propõe no ensaio estão longe de recusar um sentido político para a educação.

Nada diz mais respeito ao futuro (tanto da política quanto da educação) do que o conceito que Arendt (1992, p. 223) aponta como sen-

"Antes de mais nada, cabe lembrar que os humanistas ao se dedicarem aos seus estudos, pretendiam formar um novo homem. distante daquele que servira de modelo para os autores cristãos dos séculos anteriores. Se hoje estamos em condição de medir os limites e o alcance dessa proposta, não podemos deixar de observar que o simples fato de propor a formação de um homem à distância dos modelos conhecidos do homem cristão, dedicado à contemplação em sua forma mais perfeita, já era por si mesmo uma revolução, independente das dificuldades e mesmo das continuidades que podiam estar escondidas no processo de formação" (BIGNOTTO, 2001, p. 152-153) do a essência ${ }^{9}$ da educação: a natalidade, "o fato de que seres nascem para o mundo", isto é, de que o mundo é renovado diuturnamente por meio do nascimento. O infanticídio que Heródes encarna é um testemunho da tentativa de controlar o futuro eliminando a novidade que surgiu no mundo com o nascimento de Jesus em Belém (LARROSA, 2010). Do mesmo modo, nenhum outro conceito arendtiano aponta melhor a essência da política do que a pluralidade, sendo que a natalidade estabelece a necessária ponte entre os dois âmbitos, uma vez que as ações políticas não apenas têm o dom de iniciar algo novo e inusitado no mundo, mas também representam a revelação daquela singularidade que veio ao mundo com o nascimento de um alguém. Não é à toa que, no ensaio "Ideologia e terror", mais tarde incorporado a Origens do totalitarismo, Arendt (1989, p. 518) declara:

Do ponto de vista totalitário, o fato de que os homens nascem e morrem não pode ser senão um modo aborrecido de interferir com forças superiores. O terror, portanto, como servo obediente do movimento natural ou histórico, tem de eliminar do processo não apenas a liberdade em todo sentido específico, mas a própria fonte de liberdade que está no nascimento do homem e na sua capacidade de começar de novo. 
Daí a dignidade e a responsabilidade da qual se reveste a educação, uma vez que ela é um âmbito que não apenas acolhe um recém-chegado, isto é, uma singularidade, mas também retém, num longo processo de formação, a promessa desse novo alguém. O perigo - e talvez aí resida a força da distinção arendtiana entre educação e política - está na pretensão, quando não na intenção declarada, de fabricar seja esse alguém, seja o futuro. A negativa de Arendt quanto a essas pretensões, que para ela soariam totalitárias, é de que, entre as imprescindíveis tarefas da educação, está a de possibilitar àquele recém-chegado o cultivo do amor mundi (ALMEIDA, 2011), isto é, o desejo de que o mundo perdure. Nas palavras de Arendt (1992, p. 247), a “educação é ponto em que decidimos se amamos o nosso mundo o bastante para assumirmos a responsabilidade por ele e, com tal gesto, salvá-lo da ruína que seria inevitável não fosse a renovação e vinda dos novos e dos jovens".

Ora, aqui se apresenta um novo problema. Como um professor poderá assumir a responsabilidade política por um mundo em que ele próprio não se sente em casa? Em outras palavras, o que Arendt parece sugerir é que, qualquer que seja a representação que um professor faça do mundo - e o mundo é constantemente posto fora dos eixos -, é impossível educar sem algum apreço pelo mundo. O aspecto mais pungente e corajoso do ensaio é o fato de que, no centro da concepção de educação de Arendt, não está a criança, mas o mundo e a aposta que o educador faz por sua continuidade por meio do acolhimento dos novos em seu seio. $\mathrm{Na}$ contramão das chamadas pedagogias não diretivas ou da autonomia, que colocam o sujeito no centro da relação de ensino (a criança e seus interesses, opiniões, identidades), a profissão de fé do educador vislumbrado por Arendt (1992, p. 247) revela seu amor pelas crianças por

\section{[...] não expulsá-las de nosso mundo e abandoná-las a seus pró- prios recursos, e tampouco arrancar de suas mãos a oportunidade de empreender alguma coisa nova e imprevista para nós, prepa- rando-as em vez disso com antecedência para a tarefa de renovar um mundo comum.}

Essa aposta pela continuidade do mundo traz consigo algumas ambiguidades, dado o longo período de formação em que as crianças e os jovens são preparados para "a tarefa de renovar um mundo comum". Ao mesmo tempo em que assume a responsabilidade pelo mundo e pelo ensino de um legado de tradições, o educador protege esse mesmo mundo do assédio que irrompe dos novos. Mas isso não é tudo. O educador que não abre mão de sua autoridade e de sua responsabilidade pelo mundo e pela iniciação dos novos a esse mundo ainda deverá se esforçar por preservar a novidade em potência que habita os novos, evitando o despotismo de inventar por si mesmo essa novidade. 
Como se vê, as reflexões de Arendt impõem aos educadores um desafio ético e político da mais alta relevância. No entanto, esse desafio comporta problemas que não são autoevidentes e que, por dizerem respeito à dimensão política da educação, implicam uma melhor aproximação ao conceito de natalidade em Arendt.

\section{A DIMENSÃO POLÍTICA DA NATALIDADE NO ÂMBITO DA EDUCAÇÃO}

Agir, para Arendt (1992, p. 199), é tomar iniciativa, começar algo novo: “Os homens são livres - diferentemente de possuírem o dom da liberdade - enquanto agem, nem antes, nem depois; pois ser livre e agir são uma mesma coisa". Ela ilustra essa coincidência entre "ser livre e agir" por meio das artes em que a presença dos espectadores é que confere virtuosidade a um desempenho, seja de um músico, de um dançarino ou de um ator. Mas, em relação a esse dom essencialmente humano de iniciar algo ou, melhor dizendo, à possibilidade que a ação tem de revelar a singularidade de um alguém, Arendt é devedora de Agostinho, em cuja obra buscou inspiração para pensar o tema da natalidade. Correia (2008, p. 17, grifos nossos) observa que

\footnotetext{
[...] é pela compreensão do homem como initium e pelos conceitos de amor ao mundo e de natalidade que Agostinho é mais caro a Arendt. Com efeito, Agostinho afirmou, em uma frase que é seguramente a citação mais recorrente na obra publicada de Arendt, que "para que houvesse um início o homem foi criado, sem que antes dele ninguém o fosse".
}

Isso sugere que a natalidade não apenas contém a marca de um acontecimento único, irrepetível, mas a promessa da aparição de uma singularidade humana. Politicamente, entretanto, a natalidade é uma potencialidade, uma promessa, já que o acesso ao mundo público-político está interditado aos novos por uma espécie de moratória - variável segundo as diferentes culturas -, em razão do tempo implicado no processo de formação de um sujeito. Não deixa de ser notável que o único personagem das narrativas homéricas que se vê entrar na idade adulta seja Telêmaco, o filho de Ulisses e Penélope, e que a marca de seu ingresso - ele teria por volta de 20 anos, "idade que o jovem ateniense da época clássica se tornava membro da assembleia” (VIDAL-NAQUET, 2002, p. 86-87) - seja justamente o restabelecimento da polis (Ítaca) ao se convocar o conselho e a assembleia.

Certamente não é gratuito o fato de que, nas mais variadas culturas, o interdito do acesso ao voto cesse ao tempo final da escolaridade média, impondo-se como fronteira a separar aqueles que, segundo 
Arendt (1992, p. 160, grifo nosso), ainda não podem ser responsáveis pelo mundo, por estarem num processo de formação, ${ }^{10}$ daqueles cuja responsabilidade pelo mundo não pode ser recusada:

\begin{abstract}
No âmbito político tratamos unicamente com adultos que ultrapassaram a idade da educação propriamente dita, e a política, ou o direito de participar da condução dos negócios públicos, começa precisamente onde termina a educação [...]. Reciprocamente, em educação lidamos sempre com pessoas que não podem ser ainda admitidas na política e na igualdade, por estarem sendo preparadas para elas.
\end{abstract}

Do que foi dito até aqui, pode-se depreender que a ação política concebida em moldes arendtianos não se coaduna com as pretensões de "mudar o mundo através do ensino" por parte de um educador. A atitude conservadora sugerida por Arendt em relação à educação implica que a transformação do mundo seja uma tarefa própria ao âmbito da política. ${ }^{11}$ Assim, um educador que admita fazer de suas aulas um suposto local de ação política visando à transformação do mundo ludibria-se - ainda que com a melhor das intenções e em nome dos mais nobres princípios -, pois, inadvertidamente, realiza de fato uma forma de coerção sobre os alunos, coerção essa ainda pior do que a praticada entre adultos, a qual se dá entre cidadãos ao menos juridicamente tidos como iguais, o que não é verdadeiro em face da assimetria existente entre professores e alunos no espaço escolar. Para Arendt (1992, p. 238-239), a escola é

[...] a instituição que interpomos entre o domínio privado do lar e o mundo com o fito de fazer com que seja possível a transição, de alguma forma, da família para o mundo. Aqui [na escola], o comparecimento não é exigido pela família, e sim pelo Estado, isto é, o mundo público, e assim, em relação à criança, a escola representa em certo sentido o mundo, embora não seja ainda o mundo de fato.

Representar o mundo sem, contudo, sê-lo propriamente coloca a escola num lugar dúbio, numa fronteira. Se Arendt não nega essa dubiedade, também não pretende resolvê-la, o que é bem próprio ao seu estilo de querer compreender sem prognosticar. Como boa discípula de Sócrates, ela formula e nos lega um problema da mais alta importância, mas não o resolve. Assim, as ambiguidades entre educação e política em sua obra talvez acabem como os primeiros diálogos platônicos, isto é, intencionalmente sem solução, a fim de que cada geração se debruce novamente sobre as frágeis e por vezes delicadas fronteiras que unem e separam educação e política.
10

Mesmo no caso brasileiro, em que o direito político ao voto pode ser adquirido já aos 16 anos, os constituintes tiveram o cuidado de não o impor, mas de simplesmente o facultar aos jovens, numa clara demonstração de que eles não precisavam para usar os termos de Arendt - sentirem-se responsáveis pelo mundo.

\section{1}

Essa visão de Arendt não é compartilhada por Maria Rita César (2007, p. 41):

"Se o mundo público desejado por Hannah Arendt não existe mais e tampouco os instrumentos que possibilitariam o seu ressurgimento contemporâneo,

talvez a política deva ser re-inventada e comunidades escolares poderão ser o novo local dessa reinvenção". 
Nessa linha interpretativa, um artigo de Carvalho (1998) sugere, em relação à autoridade, que a escola não é nem deve fingir ser um espaço de igualdade no que se refere à relação entre professores e alunos, pois esta não é análoga à relação entre cidadãos. É fato que a autoridade do professor se apoia numa divisão desigual de poderes no interior da relação pedagógica. No entanto, nessa assimetria se fundamentam as escolhas que o mundo adulto fará, em momentos determinados e sempre sujeitas a reformulações, quanto ao que deve ser legado às novas gerações. Ora, isso não anula nem subtrai a responsabilidade e a autoridade do professor. Ao contrário, a autoridade

[...] deriva do fato de que ele é o agente institucional que inicia os
jovens em uma série de valores, conhecimentos, práticas e saberes
que são heranças públicas que uma nação escolheu preservar atra-
vés de sua apresentação e incorporação por parte daqueles que
são novos no mundo. Nesse sentido, somos co-autores dessas tra-
dições e a autoridade deriva etimológica e eticamente da autoria,
nesse caso, dessa co-autoria. (CARVALHO, 1998, p. 26)

Todavia, essa autoridade que legitima a ação educativa e é traduzida na responsabilidade de apresentar os novos ao mundo, isto é, iniciar crianças e jovens num mundo de heranças públicas que os precedem e que os sucederão, vem sofrendo uma severa restrição por parte do discurso pedagógico dominante. Tal restrição assume múltiplas faces. Uma delas está ligada à nossa relação com o passado, a qual, na avaliação de Tocqueville (apud ARENDT, 1992, p. 32), um homem do século XIX, já era expressa sucinta e densamente com as seguintes palavras: "Desde que o passado deixou de lançar sua luz sobre o futuro, a mente do homem vagueia nas trevas”.

Tocqueville não viveu o horror das experiências totalitárias. Depois delas, a relação passado-presente se tornou mais complexa, pois não se trata apenas de que o passado perdeu sua autoridade sobre o presente ou de que o pensar e o julgar já não possam contar mais com a luz emanada da tradição. O fato de que a ruptura esteja instalada não significa, aos olhos de Arendt, que se possa atribuir a ela o mesmo significado dado à política e à educação. Fazendo uma paráfrase, pode-se dizer que, desde que o passado deixou de lançar sua luz sobre o futuro, a mente do educador vagueia nas trevas. Mas, aos olhos dos recém-chegados, os educadores representam o presente e o passado, e não podem se furtar a estabelecer essa ponte entre si e seus alunos. É nesse diálogo intergeracional que é possível manter uma abertura para o futuro.

Entre as crianças, os jovens, os adultos e os velhos, cada qual representa simbolicamente uma melodia autônoma na suíte política de Arendt. Mas, como toda suíte, essas vozes se interpenetram. Por vezes, 
geram silêncios e até ruídos, mas também acordes maiores, que costumam ser alegres, ou menores, quase sempre tristes. Não é raro que resultem numa dissonância, sugerindo uma tensão que pode ou não se resolver naquele acorde fundamental e reconfortante aos ouvidos. O fato é que todas as melodias ali presentes, ainda que surgidas em diferentes tempos, podem resultar em ouvidos abertos ao futuro, mesmo que de maneiras distintas.

Quando visto à luz do prefácio de Entre o passado e o futuro - especificamente em relação à metáfora de que os ensaios ali reunidos poderiam ser tomados qual uma suíte musical -, o divórcio que Arendt sugere entre educação e política parece mais um exercício ao piano para seis mãos do que uma fronteira rígida e impermeável. Nesse hipotético exercício, não é difícil imaginar, à esquerda do piano, um senhor octogenário de cabelos brancos; ao centro, o filho, um adulto de meia idade; à direita, o neto. A pauta de uma peça para piano, dada a extensão sonora do instrumento, apresenta duas claves para leitura. A clave de fá, mais grave, é a escolhida pelo avô. Ao filho, coube ler as duas claves. Ao neto, reserva-se a leitura da clave de sol, mais aguda, porém mais brilhante. Eles penam para tocar uma peça anônima: Educação em tempos sombrios. $\mathrm{O}$ avô começa gravemente. Pouco depois, o filho acrescenta um acorde a mais que se harmoniza com aquela abertura. Por fim, o neto entra triunfal com seu solo agudo e ágil. Para quem assiste, parece pouco piano para muitas mãos, e, em determinado momento, elas inevitavelmente se cruzam, tocam-se, e eles se veem obrigados a recomeçar outra vez.

Essa imagem talvez revele melhor o sentido da fronteira entre educação e política. Não para negar a dimensão política da educação, mas para recusar que essa mútua implicação autorize a total indistinção, isto é, a diluição da política na educação e da educação na política. Mas ela também revela que o diálogo entre as gerações implica a partilha de uma herança, um tesouro a ser revelado ou ao menos as pistas para encontrá-lo. Esse diálogo é, antes de tudo, uma brecha que se abre no tempo, uma espécie de agora congelado em que desfilam o passado e o futuro.

\section{UMA HERANÇA SEM TESTAMENTO}

No prefácio de Entre o passado e o futuro, Arendt (1992) reflete com notável densidade sobre o problema da temporalidade e da perda de orientação ocasionado pela terrível experiência da Segunda Guerra e do Holocausto. Ela abre o texto com este aforismo do poeta René Char, que lutara na Resistência Francesa: "Nossa herança nos foi deixada sem nenhum testamento”. E Arendt (1992, p. 31) conclui: 


\begin{abstract}
O testamento, dizendo ao herdeiro o que será seu de direito, lega posses de um passado para um futuro. Sem testamento ou, resolvendo a metáfora, sem tradição - que selecione e nomeie, que transmita e preserve, que indique onde se encontram os tesouros e qual o seu valor - parece não haver nenhuma continuidade consciente no tempo, e portanto, humanamente falando, nem passado nem futuro.
\end{abstract}

Essa reflexão política que problematiza a ideia da durabilidade do mundo revela como Arendt, Tocqueville e Char compartilham aquela admiração pelo passado que não se confunde com nostalgia nem com melancolia, mas que reflete uma aguda percepção de que o presente é uma fissura entre forças que se opõem - o passado e o futuro - e de que é nessa brecha que se instaura o pensamento.

Num ensaio cujo mote é o esvaziamento da política no mundo contemporâneo, o filósofo Franklin Silva (2001) empreende uma refinada análise sobre a temporalidade que atualiza a questão deixada em aberto por Arendt e tem profundas implicações quanto à dignidade da educação. Diz ele que as ideias de passado, presente e futuro vêm perdendo densidade. Tomando como exemplo a noção de progresso do Iluminismo, mostra que o otimismo iluminista tinha uma dívida com o presente, ao qual estava indissoluvelmente ligado, de forma que a estabilidade do presente era a própria medida pela qual se fiava o futuro.

Entretanto, o filósofo adverte que o móbil da mudança passa hoje por uma transformação profunda: não é mais a estabilidade do presente que joga luz no futuro, mas é sua instabilidade que fornece a chave para se viver e compreender as mudanças que se operam à nossa volta. Entretanto, a densidade do problema da instabilidade vai mais longe, pois, se o presente já não confere mais aquela estabilidade, isso se deve ao fato de que ele é vivido e percebido como movimento e mudança, isto é,

[...] como se sua realidade the fosse emprestada pelo futuro para o qual ele tende em seu movimento [...]. O que ocorre verdadeiramente é que o futuro como que distendeu-se, esticando-se para trás e tomando o lugar do presente. [...] Pois o futuro deixou de estar além do presente, [como na perspectiva iluminista] à nossa frente, para estar no presente e em nós, como se fora uma invasão do presente pelo futuro. (SILVA, 2001, p. 241)

Ainda que a educação não seja o escopo do artigo - Silva tem em mira o esvanecimento da política em razão de uma tecnocracia -, é instigante pensar suas implicações no âmbito educacional, pois, se a transformação a que se refere o autor deitou raízes nas mais diversas esferas 
da vida contemporânea, na instituição escolar, ela se faz de modo danoso, tendendo a reduzir a educação a um meio de adaptar os estudantes aos reclamos desse futuro distendido para trás. Ora, o que ele pretende demonstrar

[...] é que a presença do futuro pesa sobre nós e quase nos oprime, porque seu significado deixou de estar relacionado com a promessa e passou a habitar o nosso presente, usurpando esse presente e de alguma maneira fazendo com que ele recue para o passado. [...] Se nos tornamos prisioneiros de um futuro "presentificado", é porque nos apropriamos de nosso futuro de maneira "irreflexiva e irrefletida". (SILVA, 2001, p. 241-242)

Note-se que a irreflexão se instaura porque o presente perdeu sua densidade com o esvanecimento da política. Silva não faz qualquer menção a Arendt ao longo do artigo, mas o diálogo e a similaridade com o pensamento da autora são inegáveis, especialmente em torno do conceito de movimento utilizado pelos nazistas e ao qual Arendt (1989, p. 515-517) consagra amplo espaço de análise em Origens do totalitarismo:

Embora os nazistas falassem da lei da natureza e os bolchevistas
falem da lei da história, natureza e história deixam de ser a força
estabilizadora da autoridade para as ações dos homens mortais;
elas próprias tornam-se movimentos [...]. O terror é a realização
da lei do movimento. O seu principal objetivo é tornar possível à
força da natureza ou da história propagar-se livremente por toda a
humanidade sem o estorvo de qualquer ação humana espontânea.

Os nazistas contavam o tempo em milhares de anos, e uma palavra recorrente em seu vocabulário era movimento. Um movimento em direção ao futuro com vistas a fabricar a humanidade perfeita sem o inconveniente daquelas partes que comprometem o todo. Para Arendt, nada nesse movimento se estabiliza - nem mesmo o terror quando suas potenciais vítimas já foram eliminadas pelo bem da espécie -, a ponto de a impermanência ser seu modus operandi. Assim, pode-se falar, paradoxalmente, de uma permanência do impermanente quando o terror torna-se prática legal, “quando a lei é a lei do movimento de alguma força sobre-humana, seja a Natureza ou a História” (ARENDT, 1989, p. 517). Voltando à análise de Silva (2001), se nada se estabiliza, se nada é permanente, como o passado pode adquirir algum significado?

Outro diálogo que se vê presente remete à questão da promessa em política, que o autor grifa para chamar atenção e que, para Arendt, era o único remédio à imprevisibilidade das ações humanas, uma vez que as promessas criam ilhas de segurança por meio de acordos mútuos. 
No entanto, é exatamente essa capacidade política de firmar acordos duradouros que está em vias de desaparecer. Voltando à educação, como ela está implicada naquela apropriação que Silva (2001) considera "irreflexiva e irrefletida” do futuro? Ou o que significa colocar ao alcance dos alunos apenas aquilo que se apoia predominantemente na superfície presente e na valorização do novo, virando as costas para o passado, aquele legado de tradições públicas e compartilhadas que os educadores deveriam confiar aos seus alunos? Ou, para falar com Carvalho (2007, p. 24), em que medida

\section{[...] num tempo que conhece a rápida obsolescência de idéias, prá- ticas sociais, valores e saberes, faz sentido ter como meta a ini- ciação dos jovens numa parcela qualquer dessa herança cultural, trazida nas disciplinas que ensinamos, nos valores que professa- mos, nos procedimentos que adotamos para julgar o verdadeiro, o justo, o belo? [...] o que se encontra de fato, em questão, é o próprio sentido formativo do conhecimento.}

Ora, e dentro dessa parcela de nossa herança cultural, qual é o sentido formativo que a instituição escolar pode ter? De que forma ela se inscreve como possibilidade de conferir alguma densidade ao passado, uma vez que a experiência totalitária projeta-se como uma sombra sobre o futuro da escolarização? Não seria, entre outras razões, voltando a Arendt (1992, p. 131), porque "memória e profundidade são o mesmo ou antes, [porque] a profundidade não pode ser alcançada pelo homem a não ser através da recordação”?

Se, de fato, não é ao educador que recai a fixação de objetivos para o futuro, num certo sentido, não representaria ele a promessa desse futuro, uma vez que aqueles que atuam para transformar o mundo lhe confiam uma memória que se vê constantemente ameaçada pelo esquecimento que pesa sobre a fragilidade de toda ação? Uma escola pode estar grávida de futuro, mas grave a escola que pretenda fabricá-lo.

\section{REFERÊNCIAS}

ABREU, Martha. Escrevendo filmes. Revista de História da Biblioteca Nacional, ano 4, n. 41, p. 98, fev. 2009.

ADORNO, Theodor W. Educação e emancipação. 2. ed. Rio de Janeiro: Paz e Terra, 2000.

ALMEIDA, Vanessa Sievers de. Educação em Hannah Arendt: entre o mundo deserto e o amor ao mundo. São Paulo: Cortez, 2011.

ARENDT, Hannah. A condição humana. Tradução de Roberto Raposo, Revisão técnica de Adriano Correia. 11. ed. Rio de Janeiro: Forense Universitária, 2010a.

ARENDT, Hannah. Lo que quiero és compreender: sobre mi vida y mi obra. Madrid: Trotta, 2010b. ARENDT, Hannah. Sobre a violência. Rio de Janeiro: Civilização Brasileira, 2009. 
ARENDT, Hannah. Compreender: formação, exílio e totalitarismo (ensaios). São Paulo: Companhia das Letras; Belo Horizonte: Editora UFMG, 2008.

ARENDT, Hannah. Sobre a revolução. Lisboa: Relógio D’ Água, 2001.

ARENDT, Hannah. Entre o passado e o futuro: seis exercícios de pensamento político. São Paulo: Perspectiva, 1992.

ARENDT, Hannah. Origens do totalitarismo. São Paulo: Companhia das Letras, 1989.

BÁRCENA, Fernando. Hannah Arendt: una filosofía de la natalidad. Barcelona: Herder, 2006.

BENVENUTI, Erica. Educação e política em Hannah Arendt: um sentido político para a separação. 2010. Dissertação (Mestrado em Educação) - Universidade de São Paulo, São Paulo, 2010.

BIGNOTTO, Newton. Origens do republicanismo moderno. Belo Horizonte: Editora UFMG, 2001.

BOTO, Carlota Reis. A escola do homem novo: entre o Iluminismo e a Revolução Francesa. São Paulo: Unesp, 1996.

CARVALHO, José Sérgio Fonseca de. Apontamentos para uma crítica das repercussões da obra de Paulo Freire. Cadernos de História e Filosofia da Educação, v. II, n. 4, p. 23-33, 1998.

CARVALHO, José Sérgio Fonseca de. A crise na educação como crise da modernidade. Revista Educação, São Paulo, n. 4, p. 16- 25, 2007. Especial Hannah Arendt pensa a educação.

CÉSAR, Maria Rita de Assis. A educação num mundo à deriva. Revista Educação, São Paulo, v. 4, p. 36-45, 2007. Especial Hannah Arendt pensa a educação.

COHN, Gabriel. Adorno e a teoria crítica da sociedade. In: ADORNO, Theodor W. Theodor Adorno (Sociologia). São Paulo: Ática, 1986. (Grandes Cientistas Sociais).

CORDEIRO, Jaime F. Parreira. Falas do novo, figuras da tradição: o novo e o tradicional na educação brasileira (anos 70 e 80). São Paulo: Editora Unesp, 2002.

CORREIA, Adriano. O significado político da natalidade: Arendt e Agostinho. In: CORREIA, Adriano; NASCIMENTO, Mariangela (Org.). Hannah Arendt: entre o passado e o futuro. Juiz de Fora: UFJF, 2008. p. 15-34.

CRUZ, Manuel. Hacerse cargo: sobre responsabilidad e identidad personal. Barcelona: Paidós, 1999.

CUSTÓDIO, Crislei de Oliveira. Educação e mundo comum em Hannah Arendt: reflexões e relações em face da crise do mundo moderno. 2011. Dissertação (Mestrado em Educação) Universidade de São Paulo, São Paulo, 2011.

DRUCKER, Claudia. O futuro da “Outra Tradição”. Revista de Sociologia e Política, Curitiba, n. 14, p. 205-208, jun. 2000.

DUARTE, André. Hannah Arendt e o pensamento político: a arte de distinguir e relacionar conceitos. Argumentos: Revista de Filosofia, Fortaleza, ano 5, n. 9, p. 39-62, jan./jun. 2013.

DUARTE, André. Educação: entre a tradição e a ruptura. Revista Educação, São Paulo, n. 4, p. 84-89, 2007. Especial Hannah Arendt pensa a educação.

DUARTE, André. 0 pensamento à sombra da ruptura: política e filosofia em Hannah Arendt. São Paulo: Paz e Terra, 2000.

LARROSA, Jorge. Pedagogia profana: danças, piruetas e mascaradas. Tradução de Alfredo VeigaNeto. 5. ed. Belo Horizonte: Autêntica, 2010.

LEFORT, Claude. Formação e autoridade: a educação humanista. In: LEFORT, Claude. Desafios da escrita política. São Paulo: Discurso, 1999.

PORCEL, Beatriz. Hannah Arendt y la crisis de nuestro tiempo. Argumentos: Revista de Filosofia, Fortaleza, ano 5, n. 9, p. 197-204, jan./jun. 2013.

SILVA, Franklin Leopoldo e. O mundo vazio: sobre a ausência da política no contexto contemporâneo. In: SILVA, Doris Accioly; MARRACH, Sonia Alem (Org.). Maurício Tragtenberg: uma vida para as ciências humanas. São Paulo: Editora Unesp, 2001. 
TAMINIAUX, Jacques. ¿Performatividad y grecomanía?. In: BIRULÉS, Fina et al. Hannah Arendt, el legado de una mirada. Sequitur: Madrid, 2008.

VIDAL, Diana Gonçalves. 80 anos do Manifesto dos Pioneiros da Educação Nova: questões para debate. Educação e Pesquisa, São Paulo, v. 39, n. 3, p. 577-588, jul./set. 2013.

VIDAL-NAQUET, Pierre. 0 mundo de Homero. Tradução de Jonatas B. Neto. São Paulo: Companhia das Letras, 2002.

VILLA, Dana. Arendt y Sócrates. In: BIRULÉS, Fina et al. Hannah Arendt, el legado de una mirada. Madrid: Sequitur, 2008.

\section{MAURÍCIO LIBERAL AUGUSTO}

Pesquisador do Grupo de Estudos em Educação e Pensamento Contemporâneo - GEEPC -, da Faculdade de Educação da Universidade de São Paulo - FE/USP -, São Paulo, São Paulo, Brasil

mlaugusto@usp.br 